\title{
Comparative assessment for hyperaccumulatory and phytoremediation capability of three wild weeds
}

\author{
Madhuri Girdhar • Neeta Raj Sharma • \\ Hasibur Rehman · Anupam Kumar • \\ Anand Mohan
}

Received: 21 September 2013/ Accepted: 3 January 2014/Published online: 19 January 2014

(C) The Author(s) 2014. This article is published with open access at Springerlink.com

\begin{abstract}
The composition and the organization of soil are changing rapidly by the diverged mankind activities, leading to the contamination of environment. Several methods are employed to clean up the environment from these kinds of contaminants, but most of them are costly and ineffective to yield optimum results. Phytoremediation is a natural green technology, which is eco-friendly for the removal of toxic metals from the polluted environment. Phytoremediation is a cost-effective technique through which the cleanup of contaminated soil laced with heavy metals is performed by wild weeds and small herbal plants. The phytoremediation technique provides a promising tool for hyperaccumulation of heavy metals; arsenic, lead, mercury, copper, chromium, and nickel, etc., by the wild weeds and that has been discussed here in detail in case of Cannabis sativa, Solanum nigrum and Rorippa globosa. In general, weeds that have the intrinsic capacity to accumulate metals into their shoots and roots, have the ability to form phytochelates and formation of stable compound with ions. This behavior of accumulation along with chelate and stable compound formation is utilized as a tool for phytoremediation activity.
\end{abstract}

Keywords Cannabis sativa - Solanum nigrum . Rorippa globosa - Hyperaccumulation · Optimum . Phytoremediation · Phytochelates · Intrinsic capacity

M. Girdhar · N. R. Sharma · A. Kumar · A. Mohan $(\bowtie)$ Department of Biotechnology, Lovely Professional University, Chehru, Phagwara, India

e-mail: anandmohan77@gmail.com

H. Rehman

Department of Biology, Faculty of Sciences, University of Tabuk, Tabuk, Saudi Arabia

\section{Introduction}

Phytoremediation is technically a collection of plant-based technologies that cause remediation of environmental pollution exploiting capability of plants or wild weeds for the remediation of contaminated soil (Cunningham et al. 1997; Flathman and Lanza 1998). Metal hyper accumulating plants have gained increased attention because of their potential to accumulate heavy metals and have application in decontamination of metal polluted soil. Acting as an integrated multidisciplinary approach for the cleanup of contaminated soils, phytoremediation combines the disciplines of plant physiology, soil microbiology, and soil chemistry (Cunningham and Ow 1996). The goal of phytoremediation is the removal of toxic metals from the soil (Reeves and Baker 2000). This current review provides the information about the various eco-friendly techniques and technologies implying to the phytoremediation process and the hyperaccumulating nature of various wild weeds (Cannabis sativa, Solanum nigrum and Rorippa globosa), which have enough capability of heavy metal accumulation. Wild weeds are suitable for this purpose because of their inherent resistant capability and their non-suitability for fodder purpose. Metals are required for a variety of metabolic processes in all organisms; however, because many metals can be toxic, plants have evolved systems to regulate the uptake and distribution of metals. The uptake of metal occurs primarily through the roots of plants, therefore this becomes the primary site for regulating their accumulation. In extreme conditions, where the metal concentration is very high in soil; leaves, roots and shoots play an important role by accumulating the metal more than required by their physiology. From various studies, it has been shown that metal concentration in leaves is $>0.1 \mathrm{mg} / \mathrm{g}$ dry weight for cadmium (Cd) metal and $>1$ 
Fig. 1 Different types of phytoremediation processes adapted from Singh et al. (2003), Suresh and Ravishankar (2004)

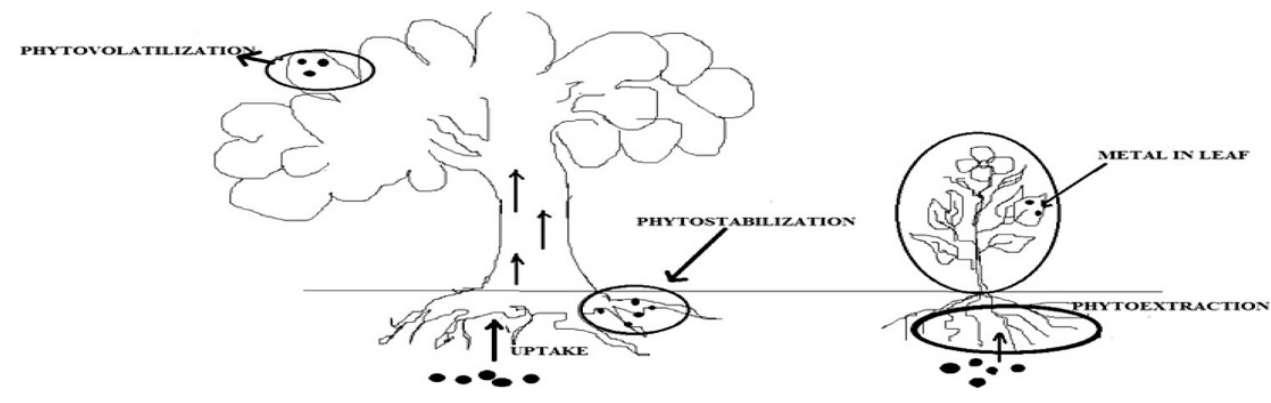

$\mathrm{mg} / \mathrm{g}$ dry weight for lead, copper, and nickel metal (Reeves and Baker 2000). Soil chemistry and soil microbiology, which is contaminated by heavy metals can be cleaned up and maintained by these accumulatory activities of such plants (Cunningham and Ow 1996). Tissues of higher plants accumulate a very high concentration of metals without showing toxicity (Klassen et al. 2000; Bennett et al. 2003).

There are various mechanisms associated with phytoremediation, phytoextraction, phytovolatization, rhizofiltration, and phytodegradation (Fig. 1). Phytoextraction is a mechanism in which plant roots absorb contaminated ground water and then transport it from roots to various parts of the plant (Salt et al. 1998). The cost involved in the phytoextraction as compared with the conventional soil remediation technique, is tenfolds less per hectare. It means phytoextraction is a cost-effective technique (Salt et al. 1995). The development of phytoextraction technique comes from the discovery of variety of wild weeds, often endemic to naturally mineralized soils that concentrate high amount of essential and non-essential heavy metals. In the same context, $R$. globosa shows Cd hyperaccumulation up to certain extent as shown in the work of Yuebing et al. (2007).

Rhizofiltration is a cost-competitive technology in the treatment of surface water or groundwater containing low but significant concentrations of heavy metals such as $\mathrm{Cr}$, $\mathrm{Pb}$, and $\mathrm{Zn}$ (Ensley 2000). Rhizofiltration can be used for metals $(\mathrm{Pb}, \mathrm{Cd}, \mathrm{Cu}, \mathrm{Ni}$, and $\mathrm{Cr})$ that are retained only within the roots. It is a phytoremediative technique designed for the removal of metals in aquatic environments. Hydroponic technique is being used in which the plants first grow in nutrient medium and then they are transferred to the metal polluted sites where the plants accumulate and concentrate the metals in their various body parts, especially roots (Flathman and Lanza 1998; Salt et al. 1995; Dushenkov et al. 1995; Zhu et al. 1999b) (Table 1).

Phytovolatization is a technique in which metals from the soil are taken up by the plant roots and by the process of transpiration they are released in the environment. This process works only when the metals are volatile in nature (Hg and Se) (USPA 2000). Apart from metals this has been
Table 1 Few natural plant metal-hyperaccumulator species and their bioaccumulation potential

\begin{tabular}{|c|c|c|c|}
\hline Metals & Plant species & $\begin{array}{l}\text { Amount } \\
{[\mathrm{gm} / \mathrm{kg} \text { (d.m.)] }}\end{array}$ & References \\
\hline $\mathrm{Cd}$ & Rorippa globosa & $>1$ & Sun et al. (2007) \\
\hline $\mathrm{Se}$ & Brassica juncea & 2.0 & Orser et al. (1999) \\
\hline $\mathrm{Cr}$ & Salsola kali & 2.9 & $\begin{array}{l}\text { Gardea-Torresday } \\
\text { et al. (2005) }\end{array}$ \\
\hline $\mathrm{Pb}$ & Thlaspi rotundifolium & $0.13-8.2$ & $\begin{array}{l}\text { Reeves and Brooks } \\
\text { (1983) }\end{array}$ \\
\hline $\mathrm{Cd}$ & $\begin{array}{l}\text { Thlaspi } \\
\quad \text { caerulescens }\end{array}$ & 10.0 & Lombi et al. (2001) \\
\hline $\mathrm{Ni}$ & Alyssum bertolonii & $>10.0$ & $\begin{array}{l}\text { Morrison et al. } \\
\text { (1980) }\end{array}$ \\
\hline $\mathrm{Co}$ & $\begin{array}{l}\text { Haumaniastrum } \\
\text { robertii }\end{array}$ & 10.2 & Brooks (1977) \\
\hline $\mathrm{Cu}$ & Ipomea & 12.3 & $\begin{array}{l}\text { Baker and Walker } \\
\text { (1990) }\end{array}$ \\
\hline $\mathrm{Mn}$ & Phytolacca acinosa & 19.3 & Xue et al. (2004) \\
\hline As & Pteris vittata & 22.6 & Ma et al. (2001) \\
\hline $\mathrm{Zn}$ & $\begin{array}{l}\text { Thlaspi } \\
\quad \text { caerulescens }\end{array}$ & 30.0 & $\begin{array}{l}\text { Baker and Walker } \\
\text { (1990) }\end{array}$ \\
\hline $\mathrm{Zn}$ & Chenopodium album $\mathrm{L}$. & 33.5 & Malik et al. (2010) \\
\hline $\mathrm{Pb}$ & Amaranthus viridis L. & $>43.0$ & Malik et al. (2010) \\
\hline $\mathrm{Cu}$ & $\begin{array}{l}\text { Parthenium } \\
\text { hysterophorus L. }\end{array}$ & 59.3 & Malik et al. (2010) \\
\hline
\end{tabular}

established in case of organic contaminants also, as in the example of Poplar tree (Liriodendron) which is a phytovolatizer, and volatilizes up to $90 \%$ of the trichloroethane absorbed from contaminated soil (McGrath and Zhao 2003).

Phytodegradation which is also known as phytotransformation is a process in which, the breakdown of contaminants occurs by plants through metabolic processes within the plant, or in the close surrounding of the plant through plant root symbiotic associations (McGrath and Zhao 2003). A metabolic process known as ex- planta occurs in which organic compounds are hydrolyzed into smaller units that can be absorbed by the plants. Some of these contaminants can be absorbed by the plant and are then broken down by plant enzymes. For the growth of the 
plant, these smaller pollutant molecules can be used as secondary metabolites for the growth of the plant (Prasad 1995).

\section{Mechanism of heavy metal uptake by plants}

There are certain works that have shown the hyperaccumulatory action of $C$. sativa on Cd-contaminated soil. Some of the projects by the US Department of Energy have explored bioavailability of cadmium in the soil and have suggested that it depends on soil $\mathrm{pH}$, redox potential, and rhizosphere chemistry. These factors determine the concentration of soluble $\mathrm{Cd}$ within the rhizosphere of the plant and the amount of Cd available for potential uptake by the plant. Soluble $\mathrm{Cd}$ could enter roots either by movement in the cell wall-free space (apoplastic pathway) or by transport across the plasma membrane (PM) of root cells and movement through the cytoplasm (symplastic pathway). The large membrane potential, which usually exists across the PM provides a driving force for the inward movement of $\mathrm{Cd}$ into cells. There are various types of channels that exist within the PM, which allow the Cd transport into the different parts of the plant. Secondary level of accumulation has been observed in stems and leaves with accumulated amount of $\mathrm{Cd}$ found to a lesser extent (Linger et al. 2005). The metals are absorbed from the soil into the roots and shoots by the process of translocation (phytoextraction). After uptake by roots, translocation into shoots is desirable because the harvest of root biomass is generally not feasible (US Department of Energy 1994). Plant uptake-translocation mechanisms are likely to be closely regulated. Plants generally do not accumulate elements beyond near-term metabolic needs, which are small ranging from 10 to $15 \mathrm{ppm}$ of most trace elements, sufficient for most of the requirements (US Department of Energy 1994). Hyperaccumulator are exceptions and can accumulate toxic metals much beyond these limits up to the levels of thousands of ppm. With this capability of hyperaccumulation, these plants could successfully be used for phytoremediation purposes. During the process contamination is translocated from roots to shoots, which are harvested, causing contamination to be removed while leaving the original soil undisturbed (US Department of Energy 1994).

Hyperaccumulatory behavior and activity is dependent upon several physiological and biochemical rationales. Polychelatin formation is one of the important basic crucial factor for the hyperaccumulatory behavior. Polychelatins are the best-characterized heavy metals chelator in plants, especially in the context of Cd tolerance (Cobbett 2000). Hemp (C. sativa) roots demonstrated a strong resistance to heavy metals and have already shown hyperaccumulatorlike potential (more than $100 \mathrm{mg} / \mathrm{kg} \mathrm{Cd}$ in dry tissue), which more likely seems to depend on the plant development stage. High values of $\mathrm{Cd}$ accumulation achieved cannot be explained exclusively by passive ion uptake. Immobilization, by binding to the cell walls, is thought to play a minor role (Sanita di Toppi and Gabbrielli 1999). Poly Chelatins are known to be synthesized from glutathione (GSH) and its derivates by enzyme phytochelatin synthase in the presence of heavy metal ions (Cobbett 2000; Rea et al. 2004). The synthesis of polychelatin occurs in cytosol. With exposure of metal to the root of the plant, polychelatins coordinate to form ligand complexes with these metals, which are further sequestered into the vacuole. GSH also has a role in defense against heavy metals.

The other class of significantly notable chelating compound is metallothioneins. They are known to have a significant role in the detoxification of metals, and the induction of their synthesis in the plants occurs through exposure of root cells to heavy metals (Rauser 1999; Cobbett 2000; Clemens 2001; Hall 2002; Cobbett and Goldsbrough 2002; Rea et al. 2004). Metallothioneins (MTs) are sulfur-rich proteins of 60-80 amino acids and are known to contain 9-16 cysteine residues and are found in plants, animals and some prokaryotes (Rauser 1999; Cobbett 2000; Cobbett and Goldsbrough 2002). These cysteine-rich polypeptides exploit the property of heavy metals to bind to the thiol-groups of proteins and detoxify them. Other well-known property of MTs is to participate in $\mathrm{Cu}$ homeostasis (Cobbett and Goldsbrough 2002).

Polyamines are small and universal polycations involved in numerous processes of plant growth and development and have anti-senescence and anti-stress effects. These distressing effects are owned due to their acid neutralizing and antioxidant properties, along with their membrane and cell wall stabilizing abilities (Zhao and Yang 2008). Technically, polyamines strengthen the defense response of plants and modulate their activity against diverse environmental stresses including metal toxicity (Groppa et al. 2003), oxidative stress (Rider et al. 2007), drought (Yamaguchi et al. 2007), salinity (Duan et al. 2008) and chilling stress (Cuevas et al. 2008; Groppa and Benavides 2008). The accurate role of polyamines found in plants under metal stress has not been deduced yet. The most positive assumption regarding the functionality of polyamines is the protection of membrane systems and their stabilization from the toxic effects of metal ions, particularly the redox active metals. Spermine, spermidine, putrescine and cadaverine are some of the important polyamines, which have demonstrated the ability to scavenge free radicals in vitro (Drolet et al. 1986). Polyamines are also known to block the major vacuolar channels, the fast vacuolar cation channel. The accumulation of these vacuolar channels results in decreased ion conductance at the vacuolar membrane, which facilitates metal ion compartmentation (Brüggemann et al. 1998). 


\section{Cannabis sativa general properties}

Cannabis sativa is a flowering herb which is dioecious in nature. Cannabis is rich in cannabinoids which are psychoactive and physiologically active chemical compound produced by the dioecious flowers of the herb. $C$. sativa provides antispasmodic and muscle relaxant stimulating appetite (Zajicek et al. 2003). C. sativa exhibits a great diversity with its prominence in both wild and cultivated areas, and hence can be utilized for the phytoremediation purpose (Mura et al. 2004). Native to central and southern Asia, Cannabis prefers a warm and humid climate, but are very resilient and can live in many habitats, so long as the soil $\mathrm{pH}$ is between 5 and 7 .

\section{Hyperaccumulative action by Cannabis sativa}

Different studies carried out on $C$. sativa provide the leads that it can be used as an hyperaccumulator for different toxic trace metals such as lead, cadmium, magnesium, copper, chromium, and cobalt which pose a great risk to the ecological system. As already, it has been established that the sources of these polluting metals are various anthropogenic activities such as smelting, sewage sludge distribution and automobile emissions (Foy et al. 1978; Chronopoulos et al. 1997; Prasad and Hagemeyer 1999; Dahmani-Muller et al. 2000). Hyperaccumulator plants can be used to remediate the metal-contaminated soil from these anthropogenic activities. This technology implies on the above ground harvestable plant tissues that have the phytoaccumulation capacity in the roots of plants to absorb, translocate and concentrate heavy metals from contaminated soil. The wild species which are endemic to metalliferous soil accumulate a very high concentration of metal from the soil (Baker and Brooks 1989a, b). C. sativa is also known as industrial Hemp, because it has the capability of hyperaccumulation of industrial waste. The potential of Hemp crops is known to convert the wasteland into cultivated land, especially the area contaminated with heavy metal pollution (lead, copper, zinc, and cadmium) (Angelova et al. 2004). The Hemp is well suited for phytoremediation, and the fiber quality has not been negatively affected by uptake of metal.

$\mathrm{Cd}$ is known to be one of the most phytotoxic heavy metal (Salt et al. 1995; Prasad 1995). For the soil phytoremediation, a good alternative is provided by Hemp plant (C. sativa L.). Except for roots, the highest concentrations of metal are found in leaves, whereas the lowest are typically observed in seeds (Ivanova et al. 2003). The photosynthesis pathway is influenced in two ways by the cadmium metal: (1) Cadmium metal disturbs indirectly water and ion uptake by the plant which has a negative effect on the plant water status (Seregin and Ivanov 2001).
(2) It directly affects the chloroplast apparatus after entering the leaf cells. Cd concentrations of up to $72 \mathrm{mg} / \mathrm{kg}$ (soil) had no negative effect on germination of $C$. sativa. It has been estimated from the post-conduction experiments that up to $100 \mathrm{ppm}$, there is no effect of cadmium metal on the morphological growth of $C$. sativa. The highest concentration of cadmium tolerance shown by the $C$. sativa in roots is maximum $830 \mathrm{mg} / \mathrm{kg}$ and it does not affect the growth of the plant (Linger et al. 2005).

The plant viability and vitality is affected by cadmium metal in the leaves and stem of $C$. sativa and was up to 50-100 mg Cd/kg [dry mass (d.m.)]. Control plants and plants growing on soil with $17 \mathrm{mg} \mathrm{Cd} / \mathrm{kg}$ of soil show seasonal changes in phytosynthetic performance. Under moderate cadmium concentrations, i.e., $17 \mathrm{mg} \mathrm{Cd} / \mathrm{kg}$ of soil, Hemp could preserve growth as well as the photosynthesis apparatus, and long-term acclimatization at chronicle levels to $\mathrm{Cd}$ stress occurs. Growth on high $\mathrm{Cd}$ concentrations, i.e., above $800 \mathrm{mg} / \mathrm{kg}$ leads to a significant loss of vitality and biomass production. Shi et al. (2012) worked on 18 Hemp accessions to screen the accessions that can be cultivated in cadmium (Cd)-contaminated soils for biodiesel production. Pot experiments were carried out to evaluate the ability of Hemp for Cd tolerance and bioaccumulation when subjected to $25 \mathrm{mg} \mathrm{Cd} / \mathrm{kg}$ [dry weight (DW)] soil condition, in terms of plant growth, pigment contents, chlorophyll fluorescence and $\mathrm{Cd}$ accumulation at 45 days after seedling emergence. Pot experiment analysis were carried out and it was observed that most of the Hemp except USO-31, Shenyang and Shengmu, could grow quite well under $25 \mathrm{mg} \mathrm{Cd} / \mathrm{kg}$ (DW) soil condition. A biomass of $>0.5 \mathrm{~g} /$ plant, high tolerance factor $(68.6-92.3 \%)$ and a little reduction in pigment content and chlorophyll fluorescence under $25 \mathrm{mg} \mathrm{Cd} / \mathrm{kg}$ (DW) soil stress were observed in Yunma 1, Yunma 2, Yunma 3, Yunma 4, Qujing, Longxi, Lu'an, Xingtai, and Shuyang. The scientist concluded that these cultivars could be cultivated in $\mathrm{Cd}$ contaminated soils and had a strong tolerance to Cd stress (Shi et al. 2012). Hemp has been found to be highly cadmium-tolerant and very useful in bioaccumulation of cadmium with its superior ability to accumulate cadmium in shoots. Hemp does have a high capacity for phytostabilization. Hemp is tolerant to contaminants, has the ability to accumulate metals along with stabilization of contaminated areas and, unlike most plants used in bioremediation, it offers additional end uses. The extraction capability for heavy metals from the soil makes the Hemp (C. sativa) an excellent soil phytoremediation agent. Worldwide, Hemp can provide both an economic and sustainable solution to the contamination of soils. The utilization of various supplements of Hemp as a derived food has brought attention to the potential negative effects that could be caused due to potential metal accumulation on the health of people of 
Fig. 2 Graphical representation of accumulation of toxic heavy metals by Cannabis sativa (Malik et al. 2010)

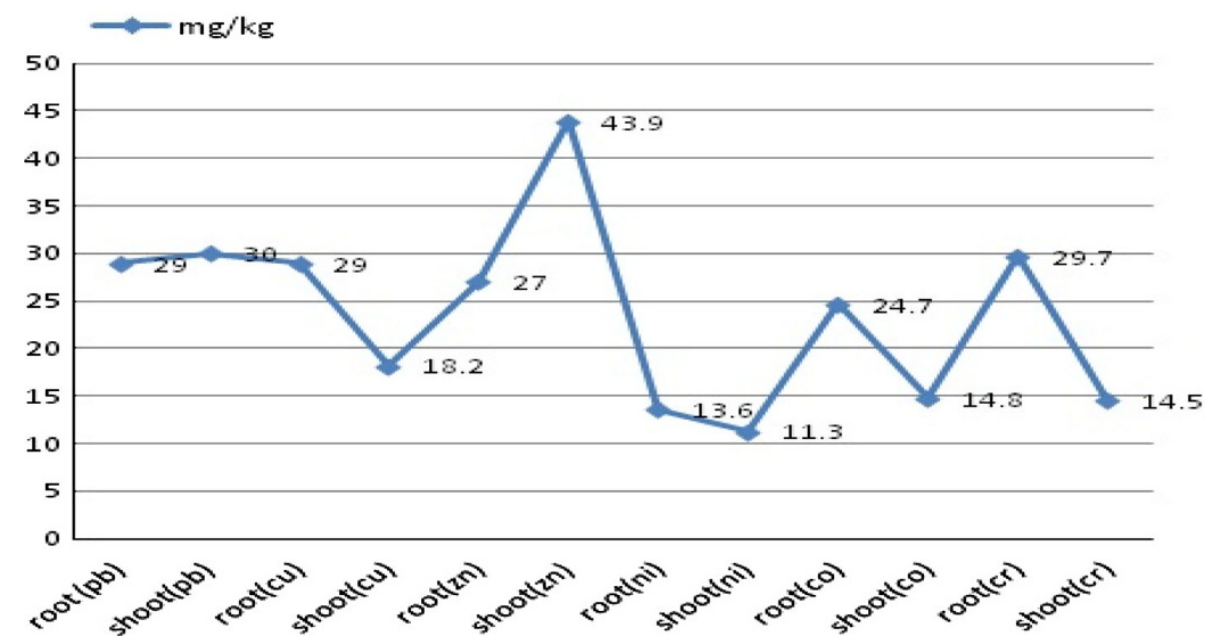

Romania reported in the recent years (Bona et al. 2007; Linger et al. 2002; Mihoc et al. 2012). The work done on the translocation rate of certain species showed that certain species have high translocation rate as compared to other. The work concluded by Malik et al. (2010) shows that $C$. sativa has high translocation rate as compared to other species for the metal $\mathrm{Zn}$ and could be used as a potential hyperaccumulator for the metal $\mathrm{Zn}$. It is estimated that the translocation factor value of $C$. sativa for $\mathrm{Zn}$ is $>1$. Due to this, the accumulation of metal $\mathrm{Zn}$ in shoots is high as compared to other heavy metals. The graph in the Fig. 2 shows the hyperaccumulation by $C$. sativa in its various tissues from contaminated soil having different heavy metals in elevated state. Investigation of metalliferous tissue of $C$. sativa leads that accumulation of zinc metal occurs maximum in shoots and it shows hyperaccumulating property by storing metal in their shoot. The least metal accumulated by $C$. sativa was $\mathrm{Ni}$ in their shoot (Table 2). In another work it was reported that the geochemical characterization of soil and the nature of crops are the factors on which the accumulation of heavy metals depends; some of them have a high potential to accumulate higher concentrations of heavy metals (Linger et al. 2002). The researchers investigated and concluded that one of the

Table 2 Hyperaccumulatory nature of Cannabis sativa is shown by the accumulation of various metals $(\mathrm{mg} / \mathrm{kg})(\mathrm{d} . \mathrm{m}$.) in industrial areas (Malik et al. 2010)

\begin{tabular}{lll}
\hline Concentration of metal $(\mathrm{mg} / \mathrm{kg})$ & Root & Shoot \\
\hline Lead & $29 \mathrm{mg} / \mathrm{kg}$ & $30 \mathrm{mg} / \mathrm{kg}$ \\
Copper & $29 \mathrm{mg} / \mathrm{kg}$ & $18.2 \mathrm{mg} / \mathrm{kg}$ \\
Zinc & $27 \mathrm{mg} / \mathrm{kg}$ & $43.9 \mathrm{~kg} / \mathrm{kg}$ \\
Nickel & $13.6 \mathrm{~kg} / \mathrm{mg}$ & $11.3 \mathrm{mg} / \mathrm{kg}$ \\
Cobalt & $24.7 \mathrm{mg} / \mathrm{kg}$ & $14.8 \mathrm{mg} / \mathrm{kg}$ \\
Chromium & $29.7 \mathrm{mg} / \mathrm{kg}$ & $14.5 \mathrm{mg} / \mathrm{kg}$ \\
\hline
\end{tabular}

Hemp variety Zenit shows high bioaccumulation rate for iron, i.e., $1,859(\mathrm{mg} / \mathrm{kg})$ as compared to the other Hemp varieties, i.e., Diana, Denise, Armanca, and Silvana (Mihoc et al. 2012) and this could possibly effect the health of people. This work brings into light the capability of specific Cannabis varieties for their extraction capability.

\section{Solanum nigrum general properties}

The common name of Solanum nigrum is black nightshade. It belongs to the Solanaceae family. S. nigrum is widely used plant in ornamental medicine. S. nigrum L. is an annual herb $0.3-1.0 \mathrm{~m}$ in height (Wei et al. 2005). It is antitumorigenic, antioxidant, anti-inflammatory, hepatoprotective, diuretic and antipyretic herb. Compounds present in the $S$. nigrum are responsible for diverse activities. Ailments such as pain, inflammation and fever are treated with $S$. nigrum as traditionally acceptable method (Zakaria et al. 2006; Lee and Lim 2003; Raju et al. 2003). The flowering season of S. nigrum is from July to September, and the seeds ripen from August to October. Herbal medication studies have proved that growth of cervical carcinoma in mice can be inhibited by this weed (Jian et al. 2008). Black nightshade is a fairly common herb, found in many wooded areas. S. nigrum grows in damp shady spots (contaminated ground) and in wastelands (Wei et al. 2005). It also grows in cultivated lands. It is a native to Europe and Asia, and further has been introduced in America, Australia and Africa through anthropogenic sources.

\section{Hyperaccumulative action by $S$. nigrum}

Solanum nigrum, a newly found hyperaccumulator, has shown the effect of cadmium toxicity on the nitrogen metabolism in their leaves (Wang et al. 2007). Cadmium is very hazardous to human health adversely affecting kidney and lungs. The activity of nitrate reductase in plants is 
inhibited due to the effect of cadmium on the uptake and transportation of nitrates by effecting the nitrate assimilation (Hernandez et al. 1997). S. nigrum could tolerate $\leq 12 \mathrm{mg} / \mathrm{kg}$ cadmium present in the soil and maintain $\mathrm{N}$ metabolism normal in the plant. However, $\mathrm{N}$ metabolism is severely inhibited at level of $48 \mathrm{mg} \mathrm{Cd} / \mathrm{kg}$. The nitrate reductase activity reduces significantly at $24 \mathrm{mg} / \mathrm{kg}$, but the activities of glutamine synthetase remains normal. $S$. nigrum appears to be an adequate species for phytoremediation of heavy metal contamination, and especially $\mathrm{Cd}$ contamination and shows the hyperaccumulating properties. The effect of addition of different fertilizers on the phytoremediation capability of S. nigrum was investigated in a study conducted by Wei et al. (2012). Under potculture system, these experiments were carried out by fertilizer addition, which increased the phytoextraction efficiencies of $S$. nigrum to $\mathrm{Cd}$ by increasing its shoot biomass. It was found that addition of chicken manure decreased the $\mathrm{Cd}$ concentrations of S. nigrum, but urea amendment did not affect organ $\mathrm{Cd}$ concentration. Considering the effect of decrease of available $\mathrm{Cd}$ in soil occurring by chicken manure, urea might be a better fertilizer for strengthening phytoextraction rate of $S$. nigrum to $\mathrm{Cd}$, and chicken manure could be a better fertilizer for phytostabilization.

$\mathrm{Zn}$ is a micronutrient for plants, at higher concentrations it may become toxic (Broker et al. 1998; Ebbs and Cochin 1997). The $\mathrm{Zn}$ accumulation by S. nigrum decreases, when manure or compost are added up to 80 and $40 \%$ but there will be an increase in the total biomass yield (Marques et al. 2008a).

S. nigrum in its efforts to remediate the metal-contaminated soil is supported by arbuscular mycorrhizal fungi (AMF). AMF occur in the soil of most ecosystems, including polluted soils. The unique structures, such as vesicles and arbuscules, are formed by the fungi belonging to the phylum Glomeromycota (Burdett 2002). The wild weeds tolerance to biotic and abiotic stresses is enhanced by the presence of AMF in the roots of the weeds present in contaminated area, as they provide a direct link between soil and roots (Joner and Leyval 1997). The availability of AMF in the roots increases the hyperaccumulation of metals by the plant. AMF are important root symbionts and partners that help in the removal of contaminants from the soil (Merharg and Cairney 2000). The fungal hyphae can extend into the soil and uptake large amounts of nutrients, including metals, to the host root. Plants provide important compounds for AMF survival; these fungi expand the contact surface between plants and soil, contributing to an enhanced plant uptake of macronutrients ( $\mathrm{Li}$ et al. 1991) such as Zn (Burkert and Robson 1994). AMF helps plants, adapt to metal-contaminated soils, either by excluding the metals or enhancing their uptake by the plant. AMF are found everywhere in most terrestrial ecosystem, forming close or symbiotic associations with the roots of the majority of plant (Smith and Read 1997). With the help of extended properties of metal absorption from soil through AMF, S. nigrum becomes highly capacitive for overall extraction of metal from contaminated soil. Apart from high absorption capacities, it also has sufficient accumulation capability and high translocation property which make $S$. nigrum an ideal tool for phytoremediation approach of metal-contaminated sites. Significantly higher level of zinc metal has been observed by workers (Marques et al. 2008a, b) in the $S$. nigrum supporting its hyperaccumulatory behavior. A good candidate for phytoremediation strategy would be a species that has good translocation of the metallic contaminant from the root to the stems and leaves, which means a higher translocation factor. High translocation factors $(\mathrm{TF}<1)$ obtained indicates that $S$. nigrum might be a good $\mathrm{Zn}$ phytoextractor, as the main metal accumulation occurs in the aboveground part of the plant.

A set of studies were carried out at Shenyang Zhangshi irrigation area, which was polluted with high amount of cadmium. S. nigrum was used in situ as a phytoremediator in Cd-polluted soil (Ji et al. 2011). Assessment of the performance of the plant over the whole growth stage was carried out. It was analyzed through experiments that aboveground biomass of single $S$. nigrum $\mathrm{L}$. grew by a factor of 190 , from $1.6 \pm 0.4$ to $300.3 \pm 30.2 \mathrm{~g}$ along with 141.2 times extractable $\mathrm{Cd}$ increase from $0.025 \pm 0.001$ to $3.53 \pm$ $0.16 \mathrm{mg}$. The data analysis also showed that the percentage of biomass and extracted $\mathrm{Cd}$ in the stem increases from 20-80 to 11-69 \%, respectively. After pot experimentations, analysis was carried out for highest $\mathrm{Cd}$ concentration in each part of $S$. nigrum plant and observed that at seedling stage the above ground biomass was $16.1 \pm 1.1 \mathrm{mg} / \mathrm{kg}$, in stem it was observed as $12.4 \pm 1.1 \mathrm{mg} / \mathrm{kg}$ and in leaf the values were $24.8 \pm 2.4 \mathrm{mg} / \mathrm{kg}$. The authors suggest that the results of their work provide reference values for the future research on the application of S. nigrum L. in phytoremediation or on chemical, agricultural strategies for phytoextraction efficiency enhancement. The pot experimentation establishes S. nigrum as a Cd hyperaccumulator with a maximum concentration of $125 \mathrm{mg} / \mathrm{kg}$ (Wei et al. 2005).

The graph describes the hyperaccumulating nature of S. nigrum in metal-contaminated soil (Fig. 3). Significant $\mathrm{Zn}$ metal accumulation occurs in the root tissue of S. nigrum, and minimum accumulation is reported in their shoot tissue (Table 3).

\section{Rorippa globosa general properties}

R. globosa is an annual/perennial herb belonging to the Brassicaceae family (mustard family) and the genus 
Fig. 3 Graphical representation of accumulation of toxic heavy metals by Solanum nigrum (Malik et al. 2010)

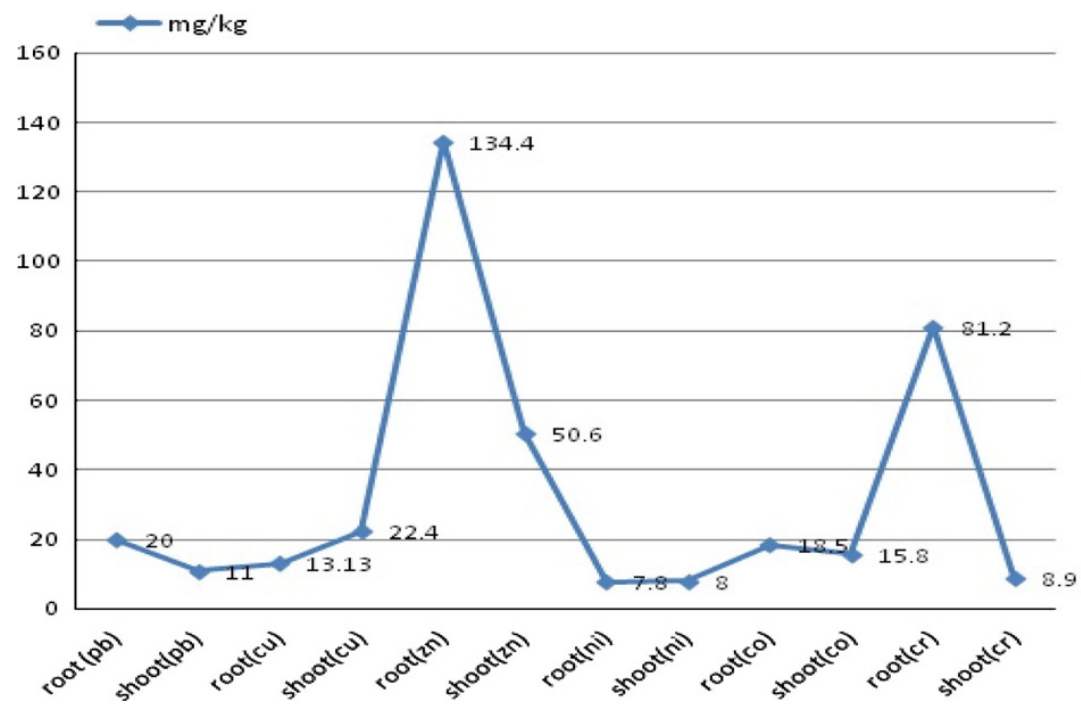

Table 3 Hyperaccumulatory nature of $S$. nigrum shown by the accumulation of various metals (mg/kg) (d.m.) in industrial areas (Malik et al. 2010)

\begin{tabular}{lll}
\hline Concentration of metal $(\mathrm{mg} / \mathrm{kg})$ & Root & Shoot \\
\hline Lead & $20 \mathrm{mg} / \mathrm{kg}$ & $11 \mathrm{mg} / \mathrm{kg}$ \\
Copper & $13.13 \mathrm{mg} / \mathrm{kg}$ & $22.2 \mathrm{mg} / \mathrm{kg}$ \\
Zinc & $134.4 \mathrm{mg} / \mathrm{kg}$ & $50.6 \mathrm{~kg} / \mathrm{kg}$ \\
Nickel & $7.8 \mathrm{~kg} / \mathrm{mg}$ & $8 \mathrm{mg} / \mathrm{kg}$ \\
Cobalt & $18.5 \mathrm{mg} / \mathrm{kg}$ & $15.8 \mathrm{mg} / \mathrm{kg}$ \\
Chromium & $81.2 \mathrm{mg} / \mathrm{kg}$ & $8.9 \mathrm{mg} / \mathrm{kg}$ \\
\hline
\end{tabular}

Rorippa (yellowcress), which grows to a height of $0.7 \mathrm{~m}$ ( $2 \mathrm{ft} 4 \mathrm{in}$.). It is a flowering plant, usually with cross shape, yellow flowers and peppery flavor. The flowering season of R. globosa is from April to November. The R. globosa is widely distributed in Europe through Central Asia, Africa, and North America. The habitat of this species is near river banks, moist areas, grasslands, and railroad embankments from near sea level to 2,500 m (Flora of China Editorial Committee 2001).

\section{Hyperaccumulative action by Rorippa globosa}

Phytoremediation-based studies work on the motive for screening out and breeding hyperaccumulative plants or hyperaccumulators that have an innate capacity to absorb and accumulate metals at higher levels (Baker and Brooks 1989a, b). The leaves of $R$. globosa show no phytotoxicity or biomass reduction when exposed to $25 \mu \mathrm{g} \mathrm{Cd} / \mathrm{g}$, and the concentration of cadmium accumulated in leaves was up to $218.9 \mu \mathrm{g} \mathrm{Cd} / \mathrm{g}$ (DW). Analysis of this study points toward strong self-protection ability of $R$. globosa toward cadmium metal by adapting oxidative stress caused by the cadmium exposure (Sun et al. 2010). An attractive feature of $R$. globosa provides its plantation capability twice in a year in metal-contaminated soils. $R$. globosa can be harvested at its flowering phase based on the site climatic conditions and growth characteristics of the hyperaccumulator. This could result with an increase in the extraction efficiency of $\mathrm{Cd}$ in shoots of $R$. globosa by $42.8 \%$ as compared to, its single maturity state when the plant was transplanted into contaminated soils (Wei and Zhou 2006).

A comparative assessment of hyperaccumulative capability of two different species of Rorippa was carried out by Wei and Twardowska (2013). Six Cd treatments were experimentally designed and treatment was given to two species $R$. globosa and $R$. palustris. Different concentrations of Cd were used, i.e., 2.5, 5, 1020 , and $40 \mathrm{mg} / \mathrm{kg}$ along with a control without $\mathrm{Cd}$ addition. The $\mathrm{Cd}$ hyperaccumulating properties of $R$. globosa showed that the cadmium in the aboveground organs was $>100 \mathrm{mg} / \mathrm{kg}$, with enrichment factor $\mathrm{EF}>1$, translocation factor $\mathrm{TF}>1$ with no significant biomass reduction at $\mathrm{Cd}$ doses $>10 \mathrm{mg} /$ $\mathrm{kg}$ and lack of such properties in $R$. palustris, which made these species suitable for comparative studies (Wei and Twardowska 2013). The total root lengths were decreased by $39,41.8$ and $46.3 \%$ expressing its tolerance limitation, when $\mathrm{Cd}$ concentrations were 10,20 and $40 \mathrm{mg} / \mathrm{kg}$. In $R$. palustris, the total root lengths when compared with the control decreased by 55.3, 64.1, and $64.4 \%$, indicating its weak tolerance ( $\mathrm{Li}$ et al. 2011). In comparative research analysis done by hydroponic experiments concluded that $R$. globosa showed high tolerance capability and acted as a good Cd hyperaccumulator as compared to the $R$. palustris.

Recent studies show that the growth of $R$. globosa is skewed by the antagonist effect caused by the $\mathrm{Cd}$ and $\mathrm{As}$ metal exposure. It was observed that, when the concentration of $\mathrm{Cd}$ in the soil was $10 \mathrm{mg} / \mathrm{kg}$ and the

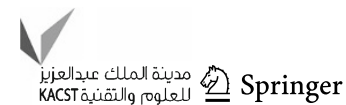


concentration of As was $50 \mathrm{mg} / \mathrm{kg}$, the plant grows up to a height of $35.9 \mathrm{~cm}$ and the dry weight of the shoots reaches up to $2.2 \mathrm{~g} /$ pot (Wei et al. 2005). At the same time, the accumulation of cadmium in the leaves under the combined stress of $\mathrm{Cd}$ and As becomes higher as compared to the same level of stress caused by the cadmium itself. At low concentration of $\mathrm{Cd}$ and As in the soil, the height and the shoot biomass of $R$. globosa increased, but the high concentrations of As and $\mathrm{Cd}$ reduce the $\mathrm{Cd}$ accumulation in the shoot of the plant by producing a synergic effect on the growth of the plant. Certain plants have the unique ability to transport, uptake and exclude various essential or nonessential metals through their roots (Fayiga et al. 2004). Exclusion and accumulation are the two main strategies that are essential to build a relationship between roots and metals. From the above study, another attractive feature of $R$. globosa comes into the picture, it has the ability to accumulate $\mathrm{Cd}$ metal into their various body parts such as stem, root, and leaves in the presence of arsenic metal, but at the same time it has the ability to exclude arsenic metal (Yang et al. 2004).

Wei and Zhou (2006) investigated Cd hyperaccumulation capacities in R. globosa, in pot experiments and concluded that to enhance the metal-removing efficiency in a year, the two-phase planting method can be utilized which measures the phytoextraction capability of plant by harvesting the plant at its flowering period. The biomass was 107.0 and $150.1 \mathrm{mg} / \mathrm{kg}$ of the $\mathrm{Cd}$ accumulation in stems and leaves, respectively, when soil $\mathrm{Cd}$ added was concentrated to $25.0 \mathrm{mg} / \mathrm{kg}$. $R$. globosa when harvested at its flowering phase yielded total dry stem and leaf biomass up to $92.3 \%$ of its full maturity, and the total cadmium concentration was up to 73.8 and $87.7 \%$ of that at the mature phase, respectively. Climatic condition of the site and the trait of the plant growth-based factors enable $R$. globosa, so that it could be transplanted into the contaminated soils twice in 1 year, by harvesting the hyperaccumulator at its flowering phase. Following the two-phase planting method, the extraction efficiency of the plant increased by $42.8 \%$ as compared to its single maturity state. This method of two-phase planting significantly helps in increasing the $\mathrm{Cd}$ hyperaccumulation in contaminated sites using the technique of phytoremediation over the course of a year.

It can be concluded that, $\mathrm{Cd}$ hyperaccumulator has the basic characteristics of weed plants and the benign feature of crops. Because of the unique features such as nutritioncompetitive ability, fast growth, high efficiency of photosynthesis, a short lifecycle and anti-pests capability, $R$. globosa has incomparable advantages compared with other hyperaccumulators and its utilization as a potential phytoremediator could have substantial advantages (Sun et al. 2007) (Table 4; Fig. 4).
Table 4 Representation of the antagonistic effect caused by the $\mathrm{Cd}$ and $\mathrm{As}$ on the bioaccumulation potential of $\mathrm{Cd}$ hyperaccumulator R. globosa (Sun et al. 2007)

\begin{tabular}{lll}
\hline $\begin{array}{l}\text { Concentration of } \\
\text { Cd and As }(\mathrm{mg} / \mathrm{kg})\end{array}$ & $\begin{array}{l}\text { Accumulation of } \\
\mathrm{Cd}(\mathrm{mg} / \mathrm{kg}) \text { in root }\end{array}$ & $\begin{array}{l}\text { Accumulation of } \\
\mathrm{Cd}(\mathrm{mg} / \mathrm{kg}) \text { in shoot }\end{array}$ \\
\hline Ck (control) & 0 & 0 \\
$\mathrm{Cd} 10+$ As50 & 0.002 & 0.09 \\
$\mathrm{Cd} 10+$ As 250 & 0 & 0.025 \\
$\mathrm{Cd} 25+$ As50 & 0.015 & 0.2 \\
$\mathrm{Cd} 25+$ As250 & 0.01 & 0.1 \\
$\mathrm{Cd} 50+$ As50 & 0.022 & 0.25 \\
$\mathrm{Cd} 50+$ As250 & 0 & 0.12 \\
\hline
\end{tabular}

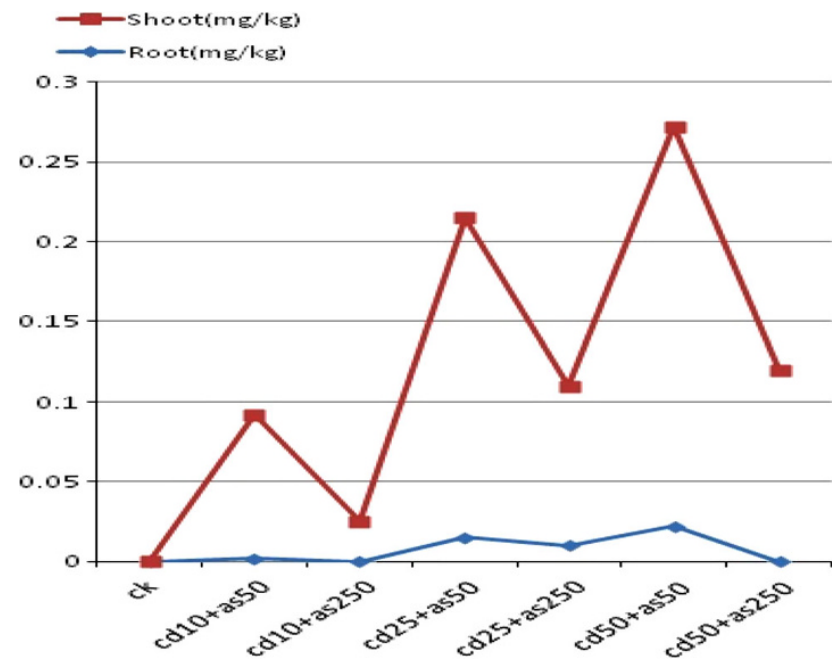

Fig. 4 Graphical representation of antagonistic effect by $\mathrm{Cd}$ and $\mathrm{As}$ on the bioaccumulation potential of $\mathrm{Cd}$ hyperaccumulator $R$. globosa (Sun et al. 2007)

\section{Conclusion}

Phytoremediation is emerging and a promising bio-based technique, which is a low-cost alternative as compared to chemical-based technologies in the clean up of heavy metalcontaminated soils. In current works, advancement is going on in various aspects of phytoremediation and for the absorption of heavy metals, where basic process understanding, responsible for the remediation processes needs to be addressed. The potential activity of wild weeds growing in metal-contaminated soil accumulates metals by showing their hyperaccumulation characteristics, and hence proving their phytoremediation mettle. In the S. nigrum, AMF play an important role in the accumulation of zinc metal. Addition of different fertilizers including chicken manure also plays an important role in stabilization and extraction protocols. C. sativa also shows the hyperaccumulation nature by accumulating cadmium metal. R. globosa also shows $\mathrm{Cd}$ 
hyperaccumulation characteristic by showing a unique property of antagonistic effect on the growth and the biomass concentration in the presence of arsenic metal. Two-phase planting methods have also been proposed in case of $R$. globosa for effective accumulation and extraction-based phytoremediation protocols for cadmium metal. The hyperaccumulating nature of plants depends on the type of species, soil quality, and its inherent control. All the weeds undertaken in the current study are capable of sufficient level of bioaccumulation, and still they are capable of maintaining their growth rates and reproduction levels as compared to controls in studies undertaken. Certain number of pilot scale studies should be planned by researchers for carrying out more analysis for finding out the capability of these weeds, so as to remove the metallic component in industrial and municipal level waste waters.

Conflict of interest No conflict of interest reported in the current work.

Open Access This article is distributed under the terms of the Creative Commons Attribution License which permits any use, distribution, and reproduction in any medium, provided the original author(s) and the source are credited.

\section{References}

Angelova V, Ivanova R, Delibaltova V, Ivanov K (2004) Bioaccumulation and distribution of heavy metals in fibre crops (flax, cotton and hemp). Ind Crops Prod 19:197-205

Baker AJM, Brooks RR (1989a) Terrestrial higher plants which hyperaccumulate metallic elements-a review of their distribution, ecology and phytochemistry. Biorecovery 1:811-826

Baker AJM, Brooks RR (1989b) Terrestrial higher plants which hyperaccumulate metallic elements-a review of their distribution, ecology and phytochemistry. Biorecovery 1:81-126

Baker AJM, Walker PL (1990) Ecophysiology of metal uptake by tolerant plants. In: Shaw AJ (ed) Heavy metal tolerance in plants: evolutionary aspects. CRC Press, Boca Raton, pp 155-177

Bennett LE, Burkhead JL, Hale KL, Terry N, Pilon M, Pilon-Smits EAH (2003) Analysis of transgenic Indian mustard plants for phytoremediation of metals-contaminated mine tailings. J Environ Qual 32:432-440

Bona E, Marsano F, Maria Cavaletto D, Berta G (2007) Proteomic characterization of copper stress response in Cannabis sativa $\mathrm{L}$. roots. Protomics 7(7):1121-1130

Broker CM, Cox FR, Tucker MR (1998) Zinc and copper toxicity in peanut, soybean, rice and corn in soil mixtures. Commun Soil Sci Plant Anal 29:2991-3005

Brooks RR (1977) Copper and cobalt uptake in Haumaniastrum sp. Plant Soil 48:541-544

Brüggemann LI, Pottosin II, Schönknecht G (1998) Cytoplasmic polyamines block the fast-activating vacuolar cation channel. Plant J 16:101-105

Burdett MC (2002) Convolution of roots and mycorrhizas of land plants. New Phytol 154(2):275-304

Burkert B, Robson A (1994) Zn uptake in subterraneum clover (Trifolium subterraneum $\mathrm{L}$.) by three vesicular arbuscular mycorrhizal fungi in a root free sandy soil. Soil Biol Biochem 26:1117e1124
Chronopoulos J, Haidouti C, Chronopoulou-Sereli A, Massas I (1997) Variations in plant and soil lead and cadmium content in urban parks in Athens, Greece. Sci Total Environ 196:91-98

Clemens S (2001) Molecular mechanisms of plant metal tolerance and homeostasis. Planta 212(4):475-486

Cobbett CS (2000) Phytochelatins and their roles in heavy metal detoxification. Plant Physiol 123:825-832

Cobbett C, Goldsbrough P (2002) Phytochelatins and metallothioneins: roles in heavy metal detoxification and homeostasis. Annu Rev Plant Biol 53:159-182

Cuevas JC, Lopez-Cobollo R, Alcazar R, Zarza X, Koncz C, Altabella $\mathrm{T}$ et al (2008) Putrescine is involved in Arabidopsis freezing tolerance and cold acclimation by regulating ABA levels in response to low temperature. Plant Physiol 148:1094-1105

Cunningham SD, Ow DW (1996) Promises and prospects of phytoremediation. Plant Physiol 110:715-719

Cunningham SD, Shann JR, Crowley D, Anderson TA (1997) Phytoremediation of contaminated water and soil. In: Kruger EL, Anderson TA, Coats JR (eds) Phytoremediation of soil and water contaminants, vol 664. American Chemical Society Symposium Series, Washington, DC, pp 2-19

Dahmani-Muller H, Van Oort F, Balabane M (2000) Strategies of heavy metal uptake by three plant species growing near a metal smelter. Environ Pollut 109:231-238

Drolet G, Dumbroff EB, Legge RL, Thompson JE (1986) Radical scavenging properties of polyamines. Phytochemistry 25:367-371

Duan JJ, Li J, Guo SR, Kang YY (2008) Exogenous spermidine affects polyamine metabolism in salinity-stressed Cucumis sativus roots and enhances short-term salinity tolerance. J Plant Physiol 165:1620-1635

Dushenkov V, Kumar PBAN, Motto H, Raskin I (1995) Rhizofiltration: the use of plants to remove heavy metals from aqueous streams. Environ Sci Technol 29:1239-1245

Ebbs SD, Cochin LV (1997) Toxicity of zinc and copper to Brassica species: implications for phytoremediation. J Environ Qual 26:776-781

Ensley BD (2000) Rational for use of phytoremediation. In: Raskin I, Ensley BD (eds) Phytoremediation of toxic metals: using plants to clean- up the environment. Wiley, New York, pp 3-12

Fayiga AO, Ma LQ, Cao XD et al (2004) Effects of heavy metals on growth and arsenic accumulation in the arsenic hyperaccumulator Pteris vittata L. Environ Pollut 132(2):289-296

Flathman PE, Lanza GR (1998) Phytoremediation: current views on an emerging green technology. J Soil Contam 7:415-432

Flora of China Editorial Committee (2001) Flora of China (Brassicaceae through Saxifragaceae). In: Wu CY, Raven PH, Hong DY (eds) Fl. China, vol 8. Science Press \& Missouri Botanical Garden Press, Beijing, pp 1-506

Foy CD, Chaney RL, White MC (1978) The physiology of metal toxicity in plants. Annu Rev Plant Physiol 29:511-566

Gardea-Torresdey JL, De la Rosa G, Peralta-Videa JR, Montes M, Cruz-Jimenez G, Cano-Aguilera I (2005) Differential uptake and transport of trivalent and hexavalent chromium by Tumbleweed (Salsola kali). Arch Environ Contam Toxicol 48:225-232

Groppa MD, Benavides MP (2008) Polyamines and abiotic stress: recent advances. Amino Acids 34:35-45

Groppa MD, Benavides MP, Tomaro ML (2003) Polyamine metabolism in sunflower and wheat leaf discs under cadmium or copper stress. Plant Sci 161:481-488

Hall JL (2002) Cellular mechanisms for heavy metal detoxification and tolerance. J Exp Bot 53:1-11

Hernandez LE, Grate A, Carlene-Ruiz R (1997) Effects of cadmium on the uptake, distribution and assimilation of nitrate in Possum sativa. Plant Soil 189:97-106 
Ivanova R, Angelova V, Delibaltova V, Ivanov K, Shamov D (2003) Accumulation of heavy metals in fibre crops flax, cotton and hemp. J Environ Prot Ecol 4:31-38

Ji P, Song Y, Sun T, Liu Y, Cao X, Xu D, Yang X, McRae T (2011) In-situ cadmium phytoremediation using Solanum nigrum L.: the bio-accumulation characteristics trail. Int $\mathrm{J}$ Phytoremediation 13:1014-1023

Jian L, Qingwang L, Tao F, Kun L (2008) Aqueous extract of Solanum nigrum inhibit growth of cervical carcinoma (U14) via modulating immune response of tumor bearing mice and inducing apoptosis of tumor cells. Fitoterapia 79(7, 8):548-556

Joner EJ, Leyval C (1997) Uptake of Cd by roots and hyphae of Glomus mosseae/Trifolium subterraneum mycorrhiza from soil amended with high and low concentration of cadmium. New Phytol 135:353e360

Klassen SP, McLean JE, Grossel PR, Sims RC (2000) Fate and behavior of lead in soils planted with metal-resistant species (River Birch and smallwing Sedge). J Environ Qual 29:1826-1834

Lee SJ, Lim KT (2003) Antioxidative effects of glycoprotein isolated from Solanum nigrum Linn on oxygen radicals and its cytotoxic effects on the MCF-7 cell. J Food Sci 68:466-470

Li XL, Marschner H, George E (1991) Acquisition of phosphorus and copper by VA mycorrhizal hyphae and root-to-shoot transport in white clover. Plant Soil 136:49e57

Li T, Di Z, Islam E, Jiang H, Yang X (2011) Rhizosphere characteristics of zinc hyperaccumulator Sedum alfredii involved in zinc accumulation. J Hazard Mater 185:818-823

Linger P, Mussing J, Fisher H, Kobert J (2002) Industrial hemp (Cannabis sativa L.) growing on heavy metal contaminated soil fibre quality and phytoremediation potential. Ind Crop Prod 16(1):33-42

Linger P, Ostwald A, Haensler J (2005) Cannabis sativa L. growing on heavy metal contaminated soil: growth, cadmium uptake and photosynthesis. Biol Plant 49(4):567-576

Lombi E, Zhao FJ, Dunham SJ, McGrath SP (2001) Phytoremediation of heavy metal-contaminated soils: natural hyperaccumulation versus chemically enhanced phytoextraction. J Environ Qual 30:1919-1926

Ma LQ, Komar KM, Tu C, Zhang W, Cai Y, Kenelly ED (2001) A fern that hyperaccumulates arsenic. Nature 409:579-582

Malik RN, Husain SZ, Nazir I (2010) Heavy metal contamination and accumulation in soil and wild plant species from industrial area of Islamabad. Pak J Bot 42(1):291-301

Marques APGC, Oliveira RS, Rangel AOSS, Castro PML (2008a) Application of manure and domestic sludge compost to contaminated soils and its effect on zinc accumulation by Solanum nigrum inoculated with different arbuscular mycorrhizal fungi. Environ Pollut 151:608-620

Marques APGC, Oliveira RS, Rangel AOSS, Castro PML (2008b) EDDS and EDTA-enhanced zinc accumulation by Solanum nigrum inoculated with arbuscular mycorrhizal fungi grown in contaminated soil. doi:10.1016/j.chemosphere.2007.08.045

McGrath SP, Zhao FJ (2003) Phytoextraction of metals and metalloids from contaminated soils. Curr Opin Biotechnol 14:277-282

Merharg AA, Cairney JWG (2000) Co-evolution of mycorrhizal symbionts and their hosts to metal-contaminated environments. Adv Ecol Res 30:69e-112

Mihoc M, Pop G, Alexa E, Radulov I (2012) Nutritive quality of Romanian hemp varieties (Cannabis sativa L.) with special focus on oil and metal contents of seeds. Chem Cent J 6:122

Morrison RS, Brooks RR, Reeves RD (1980) Nickel uptake by Alyssum sp. Plant Sci Lett 17:453-457

Mura P et al (2004) Cannabis sativa var. indica: une plante complexe aux effets pervers. Annales de Toxicologie Analytique 16:7-17
Orser CS, Salt DE, Pickering II, Epstein A, Ensley BD (1999) Brassica plants to provide enhanced mineral nutrition: selenium phytoenrichment and metabolic transformation. J Med Food $1: 253-261$

Prasad MNV (1995) Cadmium toxicity and tolerance in vascular plants. Environ Exp Bot 35:525-545

Prasad MNV, Hagemeyer J (eds) (1999) Heavy metal stress in plants-from molecules to ecosystems. Springer, Heidelberg

Raju K, Anbuganapathi G, Gokulakrishnan V et al (2003) Effect of dried fruits of Solanum nigrum Linn against CCl4-induced hepatic damage in rats. Biol Pharm Bull 26:1618-1619

Rauser WE (1999) Structure and function of metal chelators produced by plants: the case for organic acids, amino acids, phytin, and metallothioneins. Cell Biochem Biophys 31:19-48

Rea PA, Vatamaniuk OK, Rigden DJ (2004) Weeds, worms, and more. Papain's long-lost cousin, phytochelatin synthase. Plant Physiol 136:2463-2474

Reeves RD, Baker M (2000) Metal-accumulating plants. In: Raskin I, Ensley BD (eds) Phytoremediation of toxic metals: using plants to clean up the environment. Wiley, London, pp 193-230

Reeves RD, Brooks RR (1983) Hyperaccumulation of lead and zinc by two metallophytes from mining areas of Central Europe. Environ Pollut Ser A 31:277-285

Rider JE, Hacker A, Mackintosh CA, Pegg AE, Woster PM, Casero RA (2007) Spermine and spermidine mediate protection against oxidative damage caused by hydrogen peroxide. Amino Acids 33:231-240

Salt DE, Blaylock M, Kumar NPBA, Dushenkov V, Ensley D, Chet I, Raskin I (1995) Phytoremediation: a novel strategy for the removal of toxic metals from the environment using plants. Biotechnology 13:468-474

Salt DE, Smith RD, Raskin I (1998) Phytoremediation. Annu Rev Plant Phys 49:643-668

Sanita di Toppi L, Gabbrielli R (1999) Response to cadmium in higher plants. Environ Exp Bot 41:105-130

Seregin IV, Ivanov VB (2001) Physiological aspects of cadmium and lead toxic effects on higher plants. Russ J Plant Physiol 4:523-544

Shi G, Liu C, Cui M, Ma Y, Cai Q (2012) Cadmium tolerance and bioaccumulation of 18 hemp accessions. Appl Biochem Biotech 168(1):163-173

Singh OV, Labana S, Pandey G, Budhiraja R, Jain RK (2003) Phytoremediation: an overview of metallic ion decontamination from soil. Appl Microbiol Biotechnol 61:405-412

Smith SE, Read DJ (1997) Mycorrhizal symbiosis, 2nd edn. Academic Press, London

Sun Y, Zhou Q, Wei S, Ren L (2007) Growth responses of the newlydiscovered Cd-hyperaccumulator Rorippa globosa and its accumulation characteristics of $\mathrm{Cd}$ and $\mathrm{As}$ under joint stress of $\mathrm{Cd}$ and As. Front Environ Sci Eng 1:107-113

Sun R, Jin C, Zhou Q (2010) Characteristics of cadmium accumulation and tolerance in Rorippa globosa (Turcz.) Thell., a species with some characteristics of cadmium hyperaccumulation. Plant Growth Regul 61:67-74

Suresh B, Ravishankar GA (2004) Phytoremediation-a novel and promising approach for environmental clean-up. Crit Rev Biotechnol 24:97-124

United States Protection Agency (USPA) (2000) Introduction to phytoremediation. EPA 600/R-99/107. US Environmental Protection Agency, Office of Research and Development, Cincinnati. http://nepis.epa.gov/Exe/ZyPURL.cgi?Dockey=30003T7G. TXT

US Department of Energy (1994) Plume focus area, December. Mechanisms of plant uptake, translocation, and storage of toxic elements. Summary report of a workshop on phytoremediation 
research needs. http://www.osti.gov/scitech/servlets/purl/ 10109412

Wang L, Zhou Q, Ding L, Suna Y (2007) Effect of cadmium toxicity on nitrogen metabolism in leaves of Solanum nigrum L. as a newly found cadmium hyperaccumulator. J Hazard Mater 154:818-825

Wei S, Twardowska I (2013) Main rhizosphere characteristics of the Cd hyperaccumulator Rorippa globosa (Turcz.) Thell. Plant Soil 372(1-2):669-681

Wei S, Zhou QX (2006) Phytoremediation of cadmium-contaminated soils by Rorippa globosa using two-phase planting (5 pp). Environ Sci Pollut R 13(3):151-155

Wei SH, Zhou QX, Wang X et al (2005) A newly-discovered Cd hyperaccumulator Solanum nigrum L. China. Sci Bull 50:33-38

Wei S, Li Y, Zhan J, Wang S, Zhu J (2012) Tolerant mechanisms of Rorippa globosa (Turcz.) Thell. hyperaccumulating Cd explored from root morphology. Bioresour Technol 118:455-459

Xue SG, Chen YX, Reeves RD, Lin Q, Fernando DR (2004) Manganese uptake and accumulation by the hyperaccumulator plant Phytolacca acinosa Roxb. (Phytolaccaceae). Environ Pollut 131:393-399
Yamaguchi K, Takahashi Y, Berberich T, Imai A, Takahashi T, Michael AJ, Kusano T (2007) A protective role for the polyamine spermine against drought stress in Arabidopsis. Biochem Biophys Res Commun 352:486-490

Yang XE, Long XX, Ye HB et al (2004) Cadmium tolerance and hyperaccumulation in a new Zn-hyperaccumulating plant species (Sedum alfredii Hance). Plant Soil 259:181-189

Zajicek J, Fox P, Sanders H et al (2003) Cannabinoids for treatment of spasticity and other symptoms related to multiple sclerosis (CAMS study): multicentre randomised placebo controlled trial. Lancet 362:1517-1526

Zakaria ZA, Gopalan HK, Zainal H et al (2006) Antinociceptive, antiinflammatory and antipyretic effects of Solanum nigrum chloroform extract in animal models. Yakugaku Zasshi 26:1171-1178

Zhao H, Yang H (2008) Exogenous polyamines alleviate the lipid peroxidation induced by cadmium chloride stress in Malus hupehensis Rehd. Sci Hortic-Amst 116(4):442-447

Zhu YL, Bayed AM, Quean JH, De Souza M, Terry N (1999) Phytoaccumulation of trace elements by wetland plants: II. Water hyacinth. J Environ Qual 28:339-344 